\title{
ANALISIS KONTEKS DALAM CIPP (CONTEXT, INPUT, PROCESS, PRODUCT) PADA PROGRAM SKRINING INFEKSI MENULAR SEKSUAL DENGAN VOLUNTARY COUNSELLING AND TESTINGBAGI NARAPIDANA DI LEMBAGA PEMASYARAKATAN WANITA KLAS II A KOTA MALANG
}

\author{
Rosyidah Alfitri ${ }^{1}$, Argyo Demartoto ${ }^{2}$, Eti Poncorini Pamungkasari ${ }^{3}$ \\ e-mail : elfitri.mafaza@gmail.com \\ ${ }^{1}$ Diploma III Kebidanan Poltekkes RS dr Soepraoen Malang \\ ${ }^{2}$ Fakultas Ilmu Sosial dan Politik Universitas Sebelas Maret Surakarta \\ ${ }^{3}$ Fakultas Kedokteran Universitas Sebelas Maret Surakarta
}

\begin{abstract}
Abstrak
Permasalahan kesehatan ini dapat terjadi pada siapapun tanpa memandang status seseorang dalam masyarakat seperti narapidana laki-laki atau perempuan. Berdasarkan penelitian prevalensi HIV dan Sifilis pada narapidana pria $1,1 \%$ dan $5,1 \%$ sedangkan pada narapidana perempuan lebih tinggi yaitu mencapai $6 \%$ dan 8,5\%. Dari kasus tersebut maka lapas menyediakan pelayanan kesehatan dalam penanggulangan HIV/ AIDS. Tujuan penelitian untuk mengetahui Konteks dalam CIPP pada program skrining IMS dengan VCT bagi Narapidana di LP wanita Klas II A Kota Malang. Penelitian ini menggunakan metode kualitatif dengan pendekatan evaluasi. Informan kunci dalam penelitian ini adalah petugas kesehatan poliklinik LP Wanita Klas II A yang mengarahkan kepada tim IMS mobile Puskesmas Arjuno Kota Malang dan narapidana yang mengikuti skrining. Hasil penelitian didapatkan cakupan rata-rata dalam setiap bulannya $21 \mathrm{WBP}$ yang mengikuti VCT, rata-rata tersebut belum semua WBP mengikuti tes HIV. Konteks dalam pelaksanaan program skrining IMS dengan VCT di LP Wanita Klas II A Kota Malang terdiri dari Perencanaan, masalah-masalah, tujuan dan kebutuhan. Pada perencanaan terdapat MoU atau kerjasama secara tertulis dengan pihak terkait, koordinasi, konseling kepada para karyawan lapas dan narapidana, serta tanda tangan. Sedangkan pada kebutuhan terdiri atas sarana prasarana, tenaga kesehatan dan pemeriksaan. Pada masalah terdiri dari HIV dan IMS, faktor risiko dan keputihan. Terakhir pada tujuan terdiri dari angka kematian, derajat kesehatan, layanan kesehatan dan pengobatan HIV/ IMS.
\end{abstract}

Kata Kunci: CIPP, Skrining, IMS, VCT, Lapas

\section{Pendahuluan}

Salah satu permasalahan kesehatan yang menjadi perhatian baik pada negaranegara lain maupun Indonesia adalah Infeksi Menular Seksual (IMS) dan Human Immonodeficiency Virus (HIV). IMS merupakan rangkaian penyakit dengan berbagai etiologi infeksi, dimana penularan melalui hubungan seksual berperan utama dalam epidemiologi, meskipun terkadang penularannya melalui cara yang berbeda seperti dari ibu ke anak melalui darah dan transfer jaringan. Risiko penularan IMS yang tidak diketahui oleh kelompok yang berisiko, serta rendahnya kesadaran dalam pemeriksaan secara sukarela atau $\mathrm{VCT}^{1,2}$.

Salah satu cara efektif dalam mengendalikan IMS dan HIV yaitu dengan pelaporan dan pemeriksaan IMS secara rutin. World Health Organization telah menyampaikan dalam "Global Strategy for The Prevention and Control of Sexually
Transmitted Infections 2006-2015" pelaporan dan pemeriksaan IMS secara rutin ini sangat penting dan efektif sebagai sistem pemantauan IMS. Sistem pemantauan yang baik memerlukan otoritas kesehatan nasional, pemangku kebijakan, dan manajemen program IMS dengan efektif dapat memantau dan mengendalikan perkembangannya $^{3}$

Prevalensi HIV dan Sifilis pada narapidana pria adalah $1,1 \%$ dan $5,1 \%$, sedangkan pada narapidana wanita lebih tinggi yaitu mencapai $6 \%$ dan 8,5\%. Di Kota Malang orang dengan HIV terdapat penurunan pada 3 tahun terakhir, pada tahun 2014 adalah 466 orang, tahun 2015 adalah $304^{4}$.

Penyediaan fasilitas pelayanan kesehatan yang terjangkau dan dapat dimanfaatkan secara efektif merupakan hal yg utama dalam upaya pemberantasan dan penanggulangan IMS. Di negara maju 
maupun berkembang, pemeriksaan IMS dapat dipilih oleh pasien IMS dengan kemungkinan tiga pilihan diantaranya: pengobatan yang dilakukan Klinik Pemerintah (bila di Indonesia, diberikan oleh Rumah Sakit Pemerintah atau Puskesmas), Klinik Swasta atau sektor informal. Dalam menjamin terlaksananya program IMS perlu untuk diketahui bahwa pasien IMS akan mencari kombinasi dari ketiga tempat pemeriksaan. Dalam perencanaan program yang paripurna perlu dilaksanakan kegiatan dalam meningkatkan kompetensi petugas kesehatan agar mampu memberikan pelayanan IMS yang baik ${ }^{1}$.

Penelitian ini mengaplikasikan model evaluasi CIPP dikembangkan oleh Stufflebeam (2014) dengan kerangka kerja yang menyeluruh untuk mengarahkan evaluasi program, proyek, personil, produk, lembaga dan sistem. Pada penelitian ini bertujuan untuk menganalisis input pada program skrining IMS dengan VCT di LP Wanita Klas II A Kota Malang 5 .

\section{Metode Penelitian}

Penelitian ini menggunakan metode kualitatif dengan pendekatan evaluasi. Peneliti menganalisis konteks atas pelaksanaan skrining IMS dengan VCT di LP Wanita Klas II A Kota Malang. Informan tersebut dari petugas kesehatan dan pejabat lapas, tim IMS Mobile Puskesmas Arjuno Kota Malang dan Narapidana.

Informan dalam penelitian ini dipilih dengan menggunakan teknik purposive sampling dengan kriteria pelaksana program baik dari lapas maupun Puskesmas dan narapidana yang telah mengikuti skrining IMS dan VCT. Informan terdiri dari informan kunci, yaitu petugas kesehatan Lapas yang mengarahkan kepada informan utama dan triangulasi. Informan utama terdiri dari tim IMS mobile puskesmas Arjuno Kota Malang dan narapidana yang mengikuti skrining. Informan triangulasi dalam penelitian ini adalah kepala P2PL Dinas Kesehatan Kota Malang dan pejabat LP Wanita Kota Malang. Adapun jumlah informan yang didapatkan melalui purposive sampling.

Pengumpulan data dilakukan melalui wawancara mendalam dan observasi.
Peneliti menggunakan instrumen berupa panduan wawancara, dan instrumen lain menggunakan alat perekam suara serta kamera, catatan lapangan hasil observasi. Dari data penelitian kemudian dianalisis, dilakukan reduksi data, penyajian data, dan penarikan kesimpulan. Data yang didapatkan dilakukan triangulasi untuk memastikan informasi yang didapatkan ${ }^{6,7}$.

\section{Hasil dan Pembahasan}

Analisis konteks dalam skrining IMS dengan VCT di LP Wanita Klas II A Kota Malang bagi para narapidana merupakan program untuk menanggulangi HIV AIDS. Program yang diselenggarakan satu kali dalam satu bulan ini berlangsung sejak tahun 2008. Persiapan dari skrining ini adalah kerjasama dengan Dinas Kesehatan Kota Malang, sarana prasarana, tenaga kesehatan.

\section{a. Perencanaan}

Pelaksanaan skrining IMS dengan VCT di LP Wanita Klas II A Kota Malang berdasarkan ketentuan Direktur Jendral Pemasyarakatan tentang Human Immunodeficiency Virus-Acquired Immune Deficiency Syndrome.oleh ketentuan Direktur Jendral Pemasyarakatan tentang Human Immunodeficiency Virus-Acquired Immune Deficiency Syndrome Kemudian terdapat peraturan Peraturan Kementerian Kesehatan RI Nomor 74 Tahun 2014 tentang Pedoman Pelaksanaannya Konseling dan Tes HIV serta Direktorat Jenderal Pemasyarakatan - Kementerian hukum dan HAM RI, berdasarkan Peraturan Menteri Hukum dan HAM RI Nomor M.HH.01.PH.02.05 Tahun 2010 menetapkan Rencana Aksi Nasional Penanggulangan Human Immunodeficiency Virus-Acquired Immune Deficiency Syndrome dan Penyalahgunaan narkotika, Psikotropika dan Bahan adiktif Berbahaya Lainnya pada unit Pelaksana teknis Pemasyarakatan tahun 2010 - 2014. Pada Perencanaan pelaksanaan program skrining IMS dengan VCT di LP Wanita Klas II A Kota Malang, untuk MoU dilaksanakan setelah skrining IMS/VCT dilaksanakan di Lapas tahun 2008. Berikut hasil wawancara: 
“...Kita jalan dulu baru MoU, dengan dinas kesehatan. Terus rapat dilakukan dengan mengundang dinas tapi itu setelah sudah dilaksanakan skrining 2008, rapatnya itu baru 2009 apa 2010. Untuk VCT ada lebih dulu dari IMS ya dasarnya dari ketentuan Dirjen sendiri yaitu 3 zero: zero penderita $H I V$, zero kematian akibat HIV, zero diskriminasi akibat HIV. Kemudian kalo program itu dari HCPI dan GF itu mulai 2009 ya untuk bantuannya..." (IK 1. November 2016)

“...Ya...ada rapat kok dulu sekitar tahun berapa ya 2010 apa sebelumnya ya..pokok kami sudah mobile kesana kok..."(IU2. November 2016)

Untuk para WBP atau narapidana juga dilakukan wawancara, perencanaan pada saat akan dilaksanakan skrining IMS tiap bulannya, berikut hasil wawancara:

“ Sebelumnya kan ditanyain dulu, ya seperti wawancara tapi hari sebelumnya, ditanya kesediaannya juga" (IU 3.November 2016)

"Ya waktu awal masuk disini itu diwawancarai ditanya-tanya terus diberi informasi tentang $H I V$, sebelum dites itu" (IU 5. November 2016).

\section{b. Kebutuhan}

Berdasarkan analisis dokumen kebutuhan-kebutuhan yang diperlukan sesuai dengan pedoman layanan VCT dan IMS diantaranya tenaga terlatih, SOP, sarana prasarana pendukung dan laboratorium. Terdapat beberapa kebutuhan yang tidak dapat dipenuhi sendiri oleh lapas, sehingga membutuhkan kerjasama dengan pihak terkait dalam hal ini adalah Puskesmas Arjuno Kota Malang.

Hasil wawancara mendalam yang dilakukan peneliti untuk menggali informasi pada informan tentang kebutuhankebutuhan pada konteks dalam CIPP, berikut yang disampaikan oleh informan:

"Untuk kebutuhan dalam melaksanakan program ini adalah, melakukan kerjasama kepada Dinas Kesehatan Kota Malang, karena Lapas tidak mempunyai lab sendiri sehingga waktu itu terjalin dengan
Puskesmas Arjuno, bantuan reagen dari dinas juga, tenaga terlatih, konselor, dan sarana prasarana lainnyaWaktu itu beli bed gyn, sekulum dapat drop-drop an dari Dirjen yang asalnya dari HCPI. (IK.1.November 2016)

Hal ini sama hal nya yang disampaikan oleh perawat Lapas,

"Tentunya kebutuhan tenaga terlatih, alat laboratoriu dengan kerjasama dengan Dinas Kesehatan Kota Malang, ketersediaan alat, konselor dari Lapas kebetulan saya sendiri" (IK 2. November 2016)

"Jadi itu kan prinsipnya kan mereka mengajukan ke dinas untuk bantuan di Lapas untuk mobile VCT kan mereka terkendala oleh sarana prasarana dan macem-macem. Mereka mengajukan ke Dinas Kesehtan kemudian dinas menunjuk puskesmas untuk mobile kesana awalnya begitu”" (IU 1. November 2016)

c. Masalah-masalah

Dalam pelaksanaan skrining tentunya terdapat masalah-masalah yang melatarbelakangi pelaksanaan skrining IMS dengan VCT , peneliti menganalisis dokumen atau data dari para Narapidana atau tahanan, bahwa latar belakang pekerjaaan dan jenis kejahatan WBP mempunyai resiko tinggi terhadap infeksi HIV AIDS. Sebagian kasus yang menjerat para WBP adalah narkoba dan beberapa diantaranya sebagai Wanita Pekerja Seksual atau Pemandu Lagu atau Leader Caraoke (LC).

Pada saat peneliti melakukan observasi partisipan pada narapidana atau WBP terdapat beberapa yang memiliki tato atau gambar permanen yang dibuat dengan menggunakan jarum dan juga memiliki tindik selain di telinga. Masalah-masalah ini dilatarbelakangi oleh beberapa masalah sesuai dengan hasil wawancara, diantaranya:

"IMS itu kan Asymptomatis dan bisa diobati apalagi WBP itu kan mempunyai resiko terjadinya IMS atas masing-masing latar belakang mereka. Yang mendasari adanya fenomena gunung es untuk kasus 
$H I V$, dengan pelaksanaan skrining ini fenomena itu dapat terkuak. Untuk IMS, adanya faktor resiko yang dimiliki para napi disini” (IK 1. November 2016)

"Yang mendasari agar ditemukan kasus lebih cepat dan mendapat pengobatan lebih dini" (IK 2. November 2016)

"Lapas wanita itu rentan terhadap kesehatan wanitanya ya..jadi dilakukan skrininng. Juga mengingat dari asal pekerjaan dari para narapidana dan berlatar belakang kasus narkoba serta pekerjaannya itu pekerja malam. Pemakai shabu-shabu itu kan biasanya free sex sehingga kan resiko terhadap IMS dan $H I V$ " (IP 2. November 2016)

Hal ini juga disampaikan oleh narapidana/WBP, berikut hasil wawancaranya:

"Ya hasilnya kalo HIV gak langsung dikasih tau" (IU 3.November 2016)

"Ya masalahnya apa ya, mungkin pas diperiksa diambil lendirnya di vagina itu sakit" (IU 4.November 2016)

"Saya malu sama petugasnya, pas diperiksa vagina itu" (IU 6. November 2016)

"Saya takut disuntik" (IU 7. November 2016)

"Ya mungkin harus menunggu itu kan bergantian" (IU 8. November 2016)

d. Tujuan

Dalam analisis dokumen yang dilakukan oleh peneliti tujuan dari upaya penanggulangan $\mathrm{HIV} / \mathrm{IMS}$ dengan dilaksanakannya Skrining IMS dengan VCT adalah untuk mengendalikan atau menanggulangi HIV AIDS sesuai dengan ketentuan Direktur Jenderal Pemasyarakatan meminimalkan bahkan mengupayakan untuk meniadakan kematian akibat HIV AIDS serta diskriminasi terhadap ODHA pada WBP. upaya-upaya yang dilakukan melalui program skrining ini.

Pada wawancara mendalam yang dilakukan peneliti untuk menggali kepada informan terdapat tujuan atau goals. Tujuannya adalah menurunkan angka ke- matian dan kesakitan akibat HIV AIDS, berikut pernyataan informan mengenai tujuan:

"Tujuan untuk menemukan dengan cepat sehingga dapat diobati lebih dini serta untuk menurunkan angka morbiditas dan mortalitas karena HIV-IMS" (IK 1. November 2016)

"Meningkatkan derajat kesehatan WBP" (IK 2. November 2016)

"para napi yang terkena HIV kemudian IMS itu mereka sangat terawat', mereka jadi sehat. Jadi untuk akses ARV nya juga mudah jadi bisa tertangani..."(IP 3. November 2016)

"Tujuannya ya memberikan fasilitas pelayanan pemeriksaan HIV IMS kemudian skrining HIV pada kelompok beresiko kan memang di Lapas beresiko ya napinya" (IU 1. November 2016)

"Ya tujuannya untuk memberikan pelayanan karena kita mobile, jadi layanan pemeriksaan HIV IMS untuk napi" (IU 2. November 2016)

Hal ini juga diungkapakan oleh WBP yang sebagai informan, berikut pernyataannya:

"Tujuannya untuk meriksa para napi, dia kena HIV atau enggak" (IU 4. November 2016)

"Tujuannya diperiksa dan diambil darah dan lendirnya" (IU 5. November 2016)

"Kalau IMS untuk periksa keputihan, kalo VCT diambil darah untuk HIV" (IU 6. November 2016)

"Biar tahu siapa yang kena HIV'(IU 7. November 2016)

"Untuk memeriksa para napi apakah HIV apa enggak" (IU 8. November 2016)

"Untuk menemukan napi yang terkena $H I V$ ' (IU 9. November 2016)

Berdasarkan hasil evaluasi konteks program skrining IMS dengan VCT di LP Wanita Klas II A Kota Malang, terdapat masalah-masalah yang melatar belakangi pelaksanaan program adalah kasus HIV dan IMS yang terjadi pada narapidana/ WBP, dimana faktor risiko yang tinggi terjadi pada mereka, serta tempat penelitian 
merupakan Lapas wanita yang berisiko dan mempunyai keluhan keputihan, untuk mendapatkan terapi yang tepat. Seperti halnya dalam teori dijelaskan bahwa WBP memasuki lembaga pemasyarakatan memiliki resiko IMS yang tinggi diantaranya Klamidia, Gonore, Sifilis dan HIV. Perempuan yang di penjara mempunyai resiko HIV/ AIDS lebih tinggi 0,4 $\%$ dan memiliki ketergantungan narkoba dari pada laki-laki. Perilaku berisiko tersebut lebih tinggi daripada laki-laki disebabkan karena beberapa faktor yang kompleks $^{8,9}$. Dari hasil dan teori tersebut, perilaku yang berisiko pada wanita yang berada di Lapas lebih tinggi, dari pekerjaan dan latar belakang kasus yaitu sebagian besar WBP di LP Wanita Klas II A Kota Malang adalah penyalahgunaan Narkoba, sedangkan pekerjaan adalah Wanita pekerja seksual, pemandu lagu dan pekerjaan lainnya. Terbatasnya layanan skrining dan tes di Lembaga Pemasyarakatan petugas lembaga pemasyarakatan mengalami kendala dalam memperkirakan jumlah prevalensi IMS dan HIV. Dengan demikian pemeriksaan atau layanan HIV dan IMS diperlukan pada seluruh Lapas di Indonesia di setiap Lapas.

Temuan yang didapatkan peneliti, pada perencanaan program skrining IMS dengan VCT, rapat koordinasi dilaksanakan setelah program skrining IMS dengan VCT berjalan. Menurut Sulaeman (2014) dalam suatu program lintas sektoral diselenggarakan Lokakarya Mini Tribulan dengan tujuan, pembentukan tim yang dilakukan melalui dinamika kelompok; mendapatkan informasi lintas sektoral; mendapatkan informasi tentang program kesehatan; mendapatkan informasi tentang kebijakan program dan konsep baru. Hal ini dilaksanakan awal sebelum memulai suatu program $^{10}$.

Dasar-dasar pelaksanaan skrining IMS dengan VCT tertuang pada Peraturan Kementerian Kesehatan Republik Indonesia Nomor 74 tahun 2014 tentang pedoman pelaksanaannya konseling dan tes HIV, pasal 6 Ayat 1 yaitu pelayanan konseling dan tes HIV harus dilaksanakan di setiap fasilitas pelayanan kesehatan termasuk pelayanan kesehatan di lingkungan TNI/POLRI,
Lapas/rutan, tempat kerja dan fasilitas pelayanan kesehatan yang ditujukan untuk tenaga imigran ${ }^{11}$.

Kerjasama yang dilakukan dengan layanan kesehatan yaitu Dinas Kesehatan Kota Malang, untuk memberikan layanan skrining kepada WBP di Lapas. Hal ini berdasarkan Surat Edaran Nomor 129 Tahun 2013 tentang Pelaksanaan Pengendalian HIV/ AIDS dan Infeksi Menular Seksual dimana salah satu upaya adalah melaksanakan layanan kesehatan untuk Infeksi Menular Seksual dan meningkatkan penemuan atau kasus melalui skrining rutin. .

Dari kebutuhan layanan pemeriksaan HIV/ IMS yang dibutuhkan di Lapas terutama skrining IMS dengan VCT di LP Wanita Klas II A Kota Malang mempunyai tujuan dari pelaksanaan diantaranya menurunkan angka kematian dan kesakitan, meningkatkan derajat kesehatan, memberikan layanan kesehatan dan pengobatan dapat dilakukan secara tepat. Seperti halnya yang tertuang dalam teori yaitu, program skrining IMS dengan VCT merupakan sarana layanan kesehatan dengan upaya untuk menanggulangi HIV/ AIDS dengan menemukan kasus lebih awal kemudian pemberian pengobatan dan dukungan dapat dilakukan untuk mencegah penularan serta meningkatkan kualitas hidup bagi ODHA ${ }^{12}$. Dengan adanya penemuan kasus lebih dini maka pengobatan dari WBP dengan HIV pun dapat dimulai dan didampingi oleh konselor sehingga kualitas hidup ODHA sangatlah baik, mereka dapat hidup sama seperti WBP normal lainnya dalam satu blok atau kamar. Pendampingan konselor dan dukungan dari tenaga kesehatan di Lapas membuat kualitas hidup ODHA meningkat.

\section{Kesimpulan}

Program skrining IMS dengan VCT di LP Wanita Klas II A Kota Malang pada awalnya membuat perencanaan, masalahmasalah, merumuskan tujuan dan menganalisis kebutuhan-kebutuhan sehingga dapat terlaksana dengan baik sebelum pada tahap input. 


\section{Daftar Pustaka}

[1] Kementerian Kesehatan RI (2011). Pedoman Nasional Penanganan Infeksi Menular Seksual. Jakarta: Dirjen Pengendalian Penyakit dan Penyehatan Lingkungan

[2] Díez \& Díaz (2011). Sexually transmitted infections: Epidemiology and control. Epidemiology Department on HIV and Risk Behaviors. National Centre for Epidemiology. Health Institute Carlos IIIRev Esp Sanid Penit; 13: 58-66.

[3] WHO, UNODC and UNAIDS. 2007. Evidence For Action Technical Papers Interventions to Address HIV in Prisons Prevention of Sexual Transmission. Geneva

[4] Kementerian Kesehatan RI \& Kementerian Hukum dan HAM RI (2012). Pedoman Pelayanan Komprehensif HIV AIDS \& IMS di Lapas, Rutan dan Bapas. Direktorat Pengendalian Penyakit \& Penyehatan Lingkungan Kemenkes RI dan Direktorat Pemasyarakatan Kemenkumham RI

[5] Farsi M., Sharif M. (2014). Stufflebeam's Cipp \& Program Theory: A $\neg \neg$ Review. International Journal of Language Learning and Applied Linguistics World (IJLLALW) 6(3) : 400-406

[6] Idrus M. (2008). Metode Penelitian Ilmu Sosial; Pendekatan Kualitatif dan Kuantitatif Edisi Kedua. Jakarta: Erlangga

[7] Miles M, Huberman A. (2014). Analisis data Kualitatif; Buku Sumber tentang Metode-Metode Baru. Jakarta: UI-Press

[8] Binswanger, et al (2015). Gender and risk behaviors for HIV and sexually transmitted infections among recently released inmates: A prospective cohort study. AIDS Care. 26(7): 872881.

doi:10.1080/09540121.2013.859650.

[9] Wiehe SE, Rosenman MB, Aalsma MC, Scanlon ML, and Fortenberry JD (2015). Epidemiology of Sexually Transmitted Infections Among
Offenders Following Arrest or Incarceration. American Journal of Public Health. 105, No. 12

[10] Sulaeman, ES (2014). Manajemen Masalah Kesehatan Masyarakat. UNS Press: Surakarta

[11] Kementerian Kesehatan RI \& Kementerian Hukum dan HAM RI (2014). Peraturan Kementerian Kesehatan Republik Indonesia Nomor 74 tahun 2014 tentang pedoman pelaksanaannya konseling dan tes HIV. Jakarta: Kementerian Kesehatan RI

[12] Rosena DL, et al (2015). Opt-out HIV testing in prison: Informed and voluntary? AIDS Care; 27(5): 545554.doi:10.1080/09540121.2014.989 486 